perate regions of the entire northern hemisphere as far south as North Africa and Mexico, which appear to have been the southern limit of the great waves of migration of the various types of mammoths from Central Asia. This is, in fact, the climax in the history of such diverse families as the proboscideans, camels, horses, bison, and the great carnivora that preyed upon them. The impression created by the collection in a single hall of all these various types is that the period just preceding the final great glaciation of the northern hemisphere witnessed the assemblage of the most superb land mammals that the earth has produced. It is virtually the climax of the Age of Mammals, and marks the beginning of what has since proved to be the close of the Age of Mammals, because the elimination which began from natural causes during the early stages of human evolution, and reached the dimensions of a cataclysm as the Ice age progressed, has now been accelerated by the introduction of firearms. By the middle of the present century man will be alone amid the ruins of the mammalian world he has destroyed. The period of the Age of Mammals will have entirely closed, and the Age of Man will have reached a numerical climax, from which some statisticians believe it will probably recede, because we are approaching the point of the over-population of the earth in three of the five great continents.

\title{
The Rise and Development of the Sussex Iron Industry.
}

\begin{abstract}
A PAPER of considerable interest on this subject was recently read before the Newcomen Society (formed two years ago for the study of the history of engineering and technology) by Mr. Rhys Jenkins. He pointed out that although the industry in Sussex has been extinct for a hundred years, the district is historically one of great importance, for it was here that the blastfurnace was first used in England, and afterwards spread to what are now the chief ironmaking districts in the Midlands, the North, and South Wales. Although it is customary to speak of the district as Sussex, it embraces parts of Kent, Surrey, and Hampshire; in fact, it is the Weald between the North and South Downs. Sites of old iron works exist from a little beyond Haslemere on the west to Sissinghurst on the east.
\end{abstract}

It appears that iron was manufactured in the Weald in early times, and there are clear indicatPons of the existence of the industry during the Roman occupation. It is supposed to have waned with the coming of the Anglo-Saxons, and the indications of its existence are very scanty until Norman times are reached. Down to about the fifteenth century the iron was made by a direct process-i.e. the ore was reduced directly to malleable iron. Its production must have been on quite a small scale. At some period in the latter half of the fifteenth century, however, the blastfurnace was introduced into Sussex, and proved to be the forerunner of the modern process in which the ore is first smelted with the production of fluid pig-iron, and afterwards converted either into wrought iron or into one of the many varieties of steel. It was the blast-furnace which started the Wealden iron industry on its career of prosperity, and soon Sussex became the premier iron-producing district of England. It must not be imagined that there was ever anything in the nature of a "black country," for, although there were a great many works; they were scattered over a wide area, and they were small. The only fuel employed was charcoal, and the power was derived from the streams.
Mr. Jenkins reviewed at some length the evidence available, and came to the conclusion that the blast-furnace, together with the finery process for converting cast iron into malleable iron, had been introduced into England before the year I 500 ; by that date there were certainly three furnaces at work-namely, at Buxted, Hartfield, and Newbridge. The iron workers were of French origin, and this points to the method of manufacture having been borrowed from France. No doubt the old direct method of manufacture did not disappear at once, but it is probable that by the middle of the sixteenth century it had been entirely displaced. By that time a number of native workmen had been trained in the new process, and the total number of works in the district, according to a return made in the year 1548 , was fifty-three, of which about half were furnaces. The new works were established as near as possible to the sea-coast; clearly the object was to reduce, so far as possible, the expensive land transport. Every reduction in the cost of carriage placed the Sussex maker on a more favourable footing, as against the foreigner, in the London market.

The direct process had been carried out on a small scale, and produced a bloom weighing from roo $\mathrm{lb}$. to $200 \mathrm{lb}$. at a time. The manufacture could be carried on with few appliances and inexpensive erections, and entirely by human labour. It needed only a small capital outlay; obviously it was the industry of the small man. All this was changed with the coming of the blast-furnace. The furnaces, with the finery, chafery, and hammer, were comparatively expensive structures. The furnace bellows and the hammer called for more power than could be conveniently applied by workmen, so water-power was pressed into service. This meant the acquisition of an existing mill, possibly of a number of water rights, and the construction of dams or bays to form the furnace and hammer ponds, once so common a feature in Sussex. All this required an outlay of capital, probably in many cases the ownership of land, etc.; in short, iron-making was transformed

No. 2686, VOL. IO7] 
from a craft, such as that of the blacksmith, to something approaching modern capitalistic production.

In 1543 occurred a great event in the history of the industry - the founding of the first cast-iron gun at Buxted. The makers were Ralph Hogge and Peter Bawde. Hogge was the owner of the furnace, and Bawde one of the founders of bronze guns in the service of the king. The former knew how to work a furnace, and could furnish the molten iron; the latter was an expert gunfounder in bronze, and was learned in the proportions of the various pieces. The guns thus cast were very successful. As compared with bronze guns there was an enormous saving in cost, even after the founder had made a good profit and paid the carriage to London. The manufacture of these guns rapidly became a prominent feature in the Sussex trade. It seems to have been the first manufacturing industry in which the English distinguished themselves. During the reign of Elizabeth and onwards to the time of Charles II. English cast-iron guns were in demand all over the Continent. The historian Hume remarks: "Shipbuilding and the founding of iron cannon were the sole 'arts' in which the English excelled. They seem, indeed, to have possessed alone the secret of the latter, and great complaints were made every Parliament against the exportation of English ordnance." Mr. Jenkins considers that the most likely explanation of this is that the Sussex men had invented some better and cheaper method of making the moulds than that which had been in use by the founders of bronze guns.

About the middle of the sixteenth century a public outcry against the consumption of wood by the iron works was raised, and in Parliament repeated objections were urged against the works both on this ground and on the impolicy of exporting ordnance.

Mr. Jenkins carries his survey down to the time of the Protectorate, from which it appears that in I 658 there were thirty-five furnaces and forty-five forges operating in the Weald, of which twentyseven furnaces and forty-two forges were in Sussex. This appears to have been the culminating point of the iron trade of the Weald. Consideration of the further progress and decline of the industry in later years is reserved for another occasion.

\section{Long-distance Telephony.}

$\mathrm{T}^{\mathrm{H}}$ $\mathrm{E}$ progress which is being made in longdistance telephony is exemplified in the interesting demonstration last week under the direction of Col. Carty in which conversations were carried on over a composite route of more than 5500 miles made up of a 115 -mile section of submarine cable from Havana to Key West, overhead lines through Washington and New York, and right across the continent through San Francisco to Los Angeles, and, for the sake of completeness, including a 29-mile stretch of "wireless" to St. Catalina Island, in the Pacific.

There is, of course, nothing remarkable in the last-mentioned section in the point of distance, as wireless telephony is in some ways less handicapped by distance than line working; but the fact that the wireless apparatus was successfully linked up with so long a land line is noteworthy. The cable section, on the other hand, is of a length which has hitherto been beyond the limits of submarine telephony, for, as is well known, the capacity effects inseparable from such cables produce a distortion of the current waves which, when their amplitude is sufficient for audibility, nenders articulation unrecognisable. The earlier telophone cables relied upon artificially introduced inductance to counteract this effect of capacity, but, in the circuit we are speaking of, the problem has been further solved by the use of thermionic repeaters, so that waves of much smaller amplitude can be employed in the cable. The Times points out that the Havana-Key West cable is of British manufacture, and is arranged to carry, in addition to one telephone communication, four simultaneous telegraph messages.

The capacity effect of overhead land lines is also present, but is not nearly so serious as that of cables. Inductance coils, or Pupin coils, as they are called after their inventor, were employed in the New York-San Francisco line when American trans-continental telephony was first accomplished before the days of the thermionic valve; but it has now been found possible to remove them altogethes by establishing repeater stations at 250-mile intervals along the line. The same method can be, and is being, applied to assist speech over the shorter underground cables used for trunk lines in England; but, even with such assistance, it is only by the use of overhead lines that distances of thousands of miles can be bridged over by line telephony.

The demonstrations show that there is nothing technically impossible in telephoning between England and India or the Cape, for example, where only short submarine connecting links are required; but whether it would be commercially possible, owing to the great expense and difficulty of patrolling and maintaining so long an overhead line passing through every kind of territory, is another matter.

The problem of transmitting speech over such long, uninterrupted lengths of cable as across the Atlantic is not yet solved, nor does its solution appear likely in the near future. The only possibilities in this direction are those of wireless telephony, which, in the case of communication between Europe and America, is already within

No. 2686, VOL. IO7] 